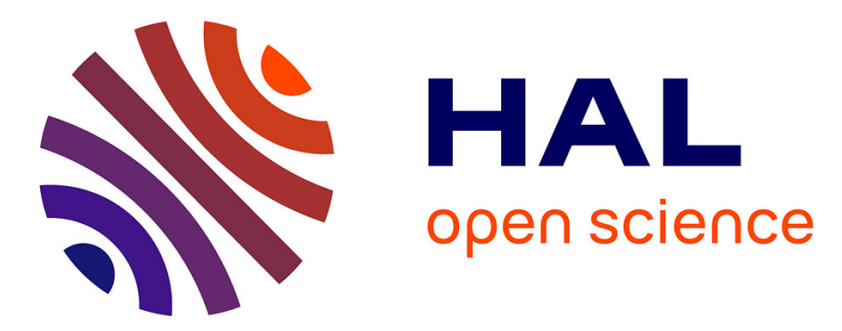

\title{
A arbitragem internacional na França e a arbitragem societária na Itália: algumas reflexões comparativas com o direito brasileiro
}

Giovanni Bonato

\section{- To cite this version:}

Giovanni Bonato. A arbitragem internacional na França e a arbitragem societária na Itália: algumas reflexões comparativas com o direito brasileiro. Revista da Faculdade de Direito da Universidade Federal de Minas Gerais, 2015, 66, pp.253-290. 10.12818/P.0304-2340.2015v66p253 . hal-01546239

\section{HAL Id: hal-01546239 \\ https://hal.parisnanterre.fr/hal-01546239}

Submitted on 25 Oct 2017

HAL is a multi-disciplinary open access archive for the deposit and dissemination of scientific research documents, whether they are published or not. The documents may come from teaching and research institutions in France or abroad, or from public or private research centers.
L'archive ouverte pluridisciplinaire HAL, est destinée au dépôt et à la diffusion de documents scientifiques de niveau recherche, publiés ou non, émanant des établissements d'enseignement et de recherche français ou étrangers, des laboratoires publics ou privés. 


\title{
A arbitragem international na França e a arbitragem societaria na Italia: algumas reflexões comparativas com o direito Brasileiro
}

\author{
THE INTERNATIONAL ARBITRATION IN \\ FRANCE AND THE CORPORATE ARBITRATION \\ IN ITALY: A COMPARATIVE REFLECTION \\ WITH THE BRAZILIAN LAW
}

Giovanni Bonato

\section{INTRODUÇÃO}

Este trabalho objetiva oferecer um panorama sintético da arbitragem na França e na Itália, com o intuito de abordar alguns aspectos peculiares do instituto que podem despertar mais a atenção dos juristas brasileiros.

Nota-se, primeiramente, que seguiremos uma perspectiva comparativa, cientes da importância de analisar as soluções oriundas de legislações estrangeiras, pois essas podem constituir uma boa fonte de inspiração tanto para introduzir novas regras quanto para chegar a uma melhor interpretação daquelas em vigor $^{1}$. Impende ressaltar a esse propósito que tal pesquisa pode

1 Sobre as utilidades do direito comparado em geral, v. DAVID, René; JAUFFRETSPINOSI, Camille, Les grands systèmes de droit contemporains, $11^{\circ}$ ed., Paris: Dalloz, 2002, p. 1 ss.

Sobre o tema, lembra TARUFFO, Michele, L'insegnamento accademico del diritto processuale civile, in Rivista trimestrale di diritto e procedura civile, Milano: Giuffré, 1996, n. 2, p. 551 ss., espec. p. 555, que "o conhecimento de outros sistemas é uma 
revelar-se particularmente proveitosa neste momento em que se cogitaa alteração de alguns artigos da Lei de Arbitragem Brasileira (LAB) n. 9.307 de 23 de setembro de 1996, com o Projeto de Lei do Senado n. 406 de 2013². Contudo, como veremos ao longo deste trabalho, uma investigação comparativa tem que levar em conta as divergências estruturais entre sistemas para evitar transpor para um determinado ordenamento algumas soluções estrangeiras que seriam com este incompatíveis ${ }^{3}$.

De antemão, é preciso esclarecer os motivos pelos quais escolhemos examinar esses dois ordenamentos.

Quanto ao direito francês da arbitragem, a escolha justifica-se em razão da sua reconhecida relevância no cenário mundial, alcançada essencialmente por meio de dois fatores positivos: a elaboração, desde os anos 1980-81, de uma legislação vanguardista, favorável ao desenvolvimento do instituto ${ }^{4}$, interpretada por uma jurisprudência amigável, notadamente em matéria internacional ${ }^{5}$,

ferramenta indispensável para elaborar reformas que tenham uma esperança de serem eficazes". Na mesma linha, sintetiza DINAMARCO, Cândido Rangel, Fundamentos do processo civil moderno, $6^{\circ}$ ed., vol. I, São Paulo: Malheiros, 2010, p. 160, que "a regra de ouro de toda comparação é a utilidade que ela possa ter para a melhor compreensão e operacionalização de pelo menos um dos sistemas jurídicos comparados".

2 Sobre esse Projeto, veja-se: WALD, Arnoldo, A reforma da lei de arbitragem (uma primeira visão), in Revista de Arbitragem e Mediação, vol. 40, São Paulo: Revista dos Tribunais, 2014, p. 17 ss.; e MARQUES, Claudia Lima; LIMA, Clarissa Costa de, Anotação ao PLS 406, de 2013 sobre arbitragem, in Revista de Direito do Consumidor, vol. 91, 2014, p. 407 ss.

3 Sobre as cautelas impostas nas investigações comparativas, veja-se DINAMARCO, Cândido Rangel, Fundamentos do processo civil moderno, cit., p. 168-170, o qual põe em evidência que "uma comparação jurídica, para ser realmente útil, precisa ser autêntica (fiel) e boa (produtora de resultados úteis e corretos)", levando em conta "certas cautelas do comparativista".

4 Sobre esse aspecto da legislação francesa da arbitragem, v.: VIGORITI, Vincenzo, Verso un diritto comune dell'arbitrato: note sul lodo e la sua impugnazione, in Foro Italiano, Bologna: Zanichelli, 1994, parte V, p. 210 ss. Acerca da importância do direito francês da arbitragem no cenário mundial, v. também nosso estudo anterior: BONATO, Giovanni, La natura e gli effetti del lodo arbitrale. Studio di diritto italiano e comparato, Nápoles: Jovene, 2012, p. 72.

5 Sobre o papel desempenhado pela jurisprudência francesa na elaboração dos princípios em matéria de arbitragem internacional, v.: ANCEL, Jean-Pierre, L'arbitrage 
e coadjuvada, na interpretação dos textos, por uma doutrina prestigiosa e brilhante ${ }^{6}$; além da presença da Câmara de Comércio Internacional em Paris. Desde já, vale lembrar que o diploma legal da arbitragem na França foi reformado pelo decreto n. 48, de 13 de janeiro de 2011, e está contido nos artigos 1442-1527 do quarto livro do Code de procédure civile (CPC) ${ }^{7}$.

No que toca ao ordenamento italiano, o seu estudo revelase estimulante em razão de algumas regras inovadoras tanto em matéria da arbitragem de direito comum (destinada a resolver qualquer tipo de controvérsias e cuja regulamentação está contida nos artigos 806-840 do Código de Processo Civil, modificados pelo decreto legislativo n. 40, de 2 de fevereiro de 2006) ${ }^{8}$, quanto

international en France (Principes et système), in AA.VV., L'arbitrage, Paris: Dalloz, 2009, p. 197 ss.; e GAILLARD, Emmanuel, La jurisprudence de la Cour de cassation em matière d'arbitrage international, in Revue de l'arbitrage, Paris: LGDJ, 2007, n. 4, p. 697 ss.

6 A esse respeito, v. HASCHER, Dominique, L'influence de la doctrine sur la jurisprudence française en matière d'arbitrage, in Revue de l'arbitrage, Paris: LGDJ, 2005 , n. 2 , p. 391 ss.

7 Sobre o direito francês da arbitragem, v.: BOLLÉE, Sylvain, Le droit français de 1'arbitrage international après le décret n. 2011-48 du 13 janvier 2011, in Revue critique de droit international privé, Paris: Dalloz, 2011, n. 2, p. 553 ss.; BONATO, Giovanni, L'ultima riforma francese dell'arbitrato, in Rivista dell'arbitrato, Milano: Giuffré, 2012, n. 3, p. 491 ss.; CLAY, Thomas (Coord.), Le nouveau droit français de 1'arbitrage, Paris: Lextenso, 2011; CLAY,Thomas, «Liberté, Égalité, Efficacité» : La devise du nouveau droit français de l'arbitrage, in Journal de droit international, Paris: Lexisnexis, 2012, n. 2 e n. 4, p. 443 ss. e p. 815; FOUCHARD, Philippe; GAILLARD, Emmanuel; GOLDMAN, Berthold, Traité de l'arbitrage commercial international, Paris: Litec, 1996; GAILLARD, Emmanuel; DE LAPASSE, Pierre, Commentaire analytique du décret du 13 janvier 2011 portant réforme du droit français de l'arbitrage, in Les Cahiers de l'arbitrage, Paris: Lextenso, 2011, n. 1, p. 263 ss.; JARROSSON, Charles; PELLERIN, Jacques, Le droit français de l'arbitrage après le décret du 13 janvier 2011, in Revue de l'arbitrage, Paris: LGDJ, 2011, n. 1, p. 5 ss.; OPPETIT, Bruno, Théorie de l'arbitrage, Paris: Puf, 1998; e SERAGLINI, Christophe; ORTSCHEIDT, Jérôme, Droit de l'arbitrage interne et international, Paris: Montchrestien, 2013.

8 Sobre o direito italiano da arbitragem, v.: BENEDETTELLI, Massimo; CONSOLO, Claudio; RADICATI DI BROZOLO, Luca, Commentario breve al diritto dell'arbitrato nazionale e internazionale, Pádua: Cedam, 2010; BERNARDINI, Pietro, L'arbitrato nel commercio internazionale e negli investimenti internazionali, $2^{\circ}$ ed., Milano: Giuffré, 2008, passim; BRIGUGLIO, Antonio; CAPPONI, Bruno, Commentario alle 
a respeito da arbitragem societária, forma especial de arbitragem voltada para dirimir os conflitos societários e que é regida pelo decreto legislativo n. 5, de 17 de janeiro de $2003^{9}$.

Advertimos que, muito embora a nossa análise tenha o foco lançado nos dois sistemas precitados, não faltarão algumas referências a alguns ordenamentos europeus.

Como no âmbito restrito deste relatório seria claramente impossível traçar um quadro exaustivo e completo do instituto, enfocaremos algumas peculiaridades da arbitragem francesa e italiana que nos parecem mais relevantes dentro da presente pesquisa comparativa. Portanto, abordaremos essencialmente dois temas: a arbitragem internacional no sistema francês, que nos levará a tratar da concepção autonomista do instituto e da questão do reconhecimento e execução na França de uma sentença arbitral estrangeira anulada

riforme del processo civile, vol. III, n. 2, Padova: Cedam, 2009; CARPI, Federico (coord.), Arbitrato, $2^{\circ}$ ed., Bologna: Zanichelli, 2007; CARPI, Federico (coord.), Gli arbitrati speciali, Bologna: Zanichelli, 2008; LA CHINA, Sergio, L'arbitrato. Il sistema e 1'esperienza, $4^{\circ}$ ed., Milano: Giuffré, 2011; MENCHINI, Sergio (coord.), La nuova disciplina dell'arbitrato, Padova: Cedam, 2010; PUNZI, Carmine, Disegno sistematico dell'arbitrato, voll. I, II e III, $2^{\circ}$ ed., Padova: Cedam, 2012; e MANDRIOLI, Cristanto; CARRATTA, Antonio, Diritto processuale civile, vol. III, $23^{\circ}$ ed., Turim: Giappichelli, 2014, p. 397 ss.

9 Sobre a arbitragem societária, v.: BIAVATI, Paolo, Il procedimento nell'arbitrato societario, in Rivista dell'arbitrato, Milano: Giuffré, 2003, n. 1, p. 27 ss.; BIAVATI, Paolo; ZUCCONI GALLI FONSECA, Elena, Arbitrato societario, in CARPI, Federico (coord.), Arbitrati speciali, cit., p. 53 ss.; BONATO, Giovanni, L'imparzialità e l'indipendenza degli arbitri alla luce della riforma del diritto societario, in LANFRANCHI, Lucio; CARRATTA, Antonio (coord.), Davanti al giudice. Studi sul processo societario, Torino: Giappichelli, 2005, p. 423 ss.; CARPI, Federico, Profili dell'arbitrato in materia di società, in Rivista dell'arbitrato, Milano: Giuffré, 2003, n. 3, p. 433 ss.; DALMOTTO, Eugenio, L'arbitrato nelle società, Padova: Zanichelli, 2013; LUISO, Francesco Paolo, Appunti sull'arbitrato societario, in Rivista di diritto processuale, Padova: Cedam, 2003, n. 3, p. 705 ss.; GRAZIOSI, Andrea. Dall'arbitrato societario al tribunale delle imprese: a dieci anni dalla riforma del diritto societario, in Rivista trimestrale di diritto e procedura civile, Milano: Giuffré, 2014, n. 1, p. 77 ss.; PUNZI, Disegno sistematico dell'arbitrato, II, cit., p. 681 ss.; RICCI, Edoardo Flavio, Il nuovo arbitrato societario, in Rivista trimestrale di diritto e procedura civile, Milano: Giuffré, 2003, n. 2, p. 517 ss.; RUFFINI, Giuseppe, La riforma dell'arbitrato societario, in Corriere Giuridico, Padova: Ipsoa, 2003, n. 11, p. 1524 ss.; e ZUCCONI GALLI FONSECA, Elena, Arbitrato societario: la Cassazione respinge la tesi del «doppiobinario», in Rivista trimestrale di diritto e procedura civile, Milano: Giuffré, 2011, n. 2, p. 629 ss. 
no país de origem; e as regras da arbitragem societária italiana, notadamente as disposições acerca da arbitrabilidade subjetiva, sobre a inserção da cláusula compromissória durante a vida da sociedade e a nomeação dos árbitros.

Antes de ingressar na análise do direito positivo atualmente em vigor, é preciso fazer uma sintética retrospectiva histórica para melhor compreendermos as disposições legais vigentes e as modernas tendências em matéria de arbitragem.

\section{A RETROSPECTIVA HISTÓRICA DA ARBITRAGEM}

Como já puseram em destaque vários estudiosos, o instituto da arbitragem foi, ao longo de todo o século XIX, objeto de um tratamentolegislativo desestimulante ${ }^{10}$.

De acordo com a ideologia da centralização do poder e da estatalidade da função jurisdicional (cujo exercício cabia somente aos juízes públicos), o Código de Processo Civil francês de 1806 e o Código de Processo Civil italiano de 1865 (e nessa mesma linha o seu sucessor, o Código italiano de 1940) adotaram uma postura adversa e desconfiada a respeito da arbitragem, instituto então encarado como uma ofensa à unidade da função judiciária estatal ${ }^{11}$. Partindo-se dessa premissa ideológica, os legisladores elaboraram um diploma legal restritivo da arbitragem, que veio a ser regulada segundo "pesadas e rigorosas formalidades" a fim de desestimular "sua utilização"12.

10 Para um panorama histórico sobre a arbitragem, v. LOQUIN, Eric, Arbitrage, Aperçu historique, Aperçu de droit comparé, in JurisClasseur, Procédure civile, fasc. 1010, Paris: Lexisnexis, 2013.

11 Sobre essa ideologia legiscêntrica do século XIX, consulte-se o ensaio de PICARDI, Nicola, ID., Le code de procédure civile français de 1806 et le monopole étatique de la juridiction, in CADIET, Loïc; CANIVET, Guy (coord.), 1806-1976-2006. De la commémoration d'un code à l'autre: 200 ans de procédure civile en France, Paris: Litec, 2006, p. 187 ss.; PUNZI, Carmine, Disegno sistematico dell'arbitrato, vol. I, p. 126 ss.

12 Nesse sentido, v. CARMONA, Carlos Alberto, A arbitragem no Código de Processo Civil brasileiro,Tese de doutorado, São Paulo, USP, 1990, p. 41; na mesma linha, MARANI, Giovanni, Aspetti negoziali e aspetti processuali dell'arbitrato, Torino: 
Dois eram, na época, os principais óbices que o legislador e a jurisprudência haviam erigido para impedir o florescimento da arbitragem na prática. De um lado, vale recordar que na França a ausência de uma disciplina legislativa expressa no CPC de 1806 acerca da cláusula compromissória levou a Corte de cassação a declarar a nulidade dessa forma de convenção em um célebre acórdão de 1843 (arrêt Prunier) ${ }^{13}$. De outro lado, na Itália, onde a cláusula compromissória era admitida pela jurisprudência ${ }^{14}$, vigorava, todavia, a regra da homologação obrigatória da sentença arbitral, segundo a qual a eficácia jurídica da decisão proferida pelos árbitros estava necessariamente ligada a um provimento judicial posterior, como dispunha o art. 24 do CPC italiano de 1865 e, posteriormente, o art. 825 do CPC italiano de $1940^{15}$.

De modo semelhante, até o advento da LAB n. 9.307/96, o legislador brasileiro empregava os dois obstáculos antes referidos no CC de 1916, no CPC de 1939 e no CPC de 1973: diante da falta de uma disciplina normativa sobre a cláusula compromissória, a jurisprudência brasileira acabou por desprestigiá-la, excluindo a execução específica dessa convenção; e, ainda, a homologação da sentença arbitral era obrigatória para que esta produzisse os mesmos efeitos da sentença estatal $^{16}$.

Unione Tipografica-Editrice Torinese, 1966, p. 90 ss.; e RUBELLIN-DEVICHI, Jacqueline, L'arbitrage. Nature juridique. Droit interne et droit international, Paris: Dalloz, 1965, p. 19.

13 Trata-se da decisão de 10 de julho de 1843, in Recueil Dalloz, Paris: Dalloz, 1843, vol. I, p. 343 ss., republicada depois na Revue de l'arbitrage, Paris: LGDJ, 1992, n. 2, p. 399 ss.

14 Por mais informações sobre a cláusula compromissória na Itália nos séculos XIX e XX, v.TENELLA SILLANI, Chiara, L'arbitrato di equità, Milano: Giuffré, 2006,p. 151.

15 A doutrina e a jurisprudência italiana chegavam a reputar a sentença arbitral desprovida de homologação como um ato juridicamente inexistente, v.: CHIOVENDA, Giuseppe, Istituzioni di diritto processuale civile, I, $2^{\circ}$ ed., Napoli: Jovene, 1935, p. 77.

16 Acerca dos dois obstáculos à utilização da arbitragem contidos no sistema brasileiro antes da lei de 1996, v. CARMONA, Carlos Alberto, Arbitragem e processo, $3^{\circ} \mathrm{ed}$., São Paulo: Atlas, 2009, pp. 4-5. 
No século XX, houve uma lenta e paulatina mudança de postura a respeito da arbitragem ${ }^{17}$. Ocorreram alguns avanços tímidos entre as duas Guerras, de modo que podemos mencionar a esse respeito o "Protocolo sobre Cláusulas Arbitrais" de Genebra de 1923 e a "Convenção para a Execução de Sentenças Arbitrais Estrangeiras" de Genebra de 1927; a admissibilidade na França da cláusula compromissória em controvérsias comerciais, trazida pela lei de 31 de dezembro de 1925; a criação nos anos trinta do século passado da noção da arbitragem internacional na jurisprudência francesa para afastar a aplicação das regras restritas e pesadas da arbitragem interna, admitindo, por conseguinte, a validade da cláusula compromissória nas controvérsias que colocam em jogo os interesses do comércio internacional (veja-se abaixo par. 3).

A mudança de postura em sentido mais favorável à arbitragem prosseguiu nos anos cinquenta e sessenta por meio de uma série de fatores: a elaboração da Convenção de Nova Iorque de 1958 sobre o "Reconhecimento e Execução de Sentenças Arbitrais Estrangeiras"; uma tomada de posição em prol da arbitragem na jurisprudência francesa, inaugurada com o acórdão Gosset de 1963 da Corte de Cassação francesa, que trouxe o princípio da autonomia da cláusula compromissória em matéria de arbitragem internacional ${ }^{18}$; o surgimento, no pensamento de alguns doutrinadores europeus, de uma nova concepção de jurisdição, conceituada como uma atividade exercível também pelos particulares e não apenas pelos juízes públicos ${ }^{19}$.

17 CARMONA, Carlos Alberto, A arbitragem no Código de Processo Civil brasileiro, cit., p. 42, escreve que: "No século XX o interesse pela arbitragem ressurge com força e, aos poucos, o instituto volta a ocupar o prestígio de outrora, renovado e fortalecido em tratados internacionais que se multiplicam".

18 O acordão Gosset, prolatado pela Corte de Cassação francesa no dia 7 de maio de 1963 (publicado em Recueil Dalloz, Paris: Dalloz, 1963, p. 545), constitui o marco inicial do novo posicionamento da jurisprudência francesa em prol da arbitragem, segundo a lição de FOUCHARD, Philippe, L'arbitrage et la mondialisation de l'économie, in Mélanges en l'honneur de Gérard Farjat, Paris: Frison-Roche ed., 1999, p. 381 ss.

19 Nessa linha, cumpre lembrar o pensamento de: DAVID, René, Arbitrage et droit comparé, in Revue internationale de droit comparé, 1959, n. 1, p. 5 ss.; CORNU, Gérard; FOYER, Jean, Procédure civile, Paris: PUF, 1958, p. 47; MOTULSKY, Henry, 
Foi, todavia, nos anos oitenta que se iniciou, sobretudo, o "vento" reformador na Europa em prol da arbitragem ${ }^{20}$ e nessa linha houve uma verdadeira "reviravolta normativa". Os legisladores europeus - cientes das vantagens trazidas pela arbitragem ${ }^{21}$ e em busca de atrair o desenvolvimento dos procedimentos internacionais no próprio território ${ }^{22}$ - alteraram e modernizaram o diploma legal do instituto, baseando-se em novas "palavras de ordem", como: autonomia, independência, liberalismo, eficácia e efetividade da arbitragem ${ }^{23}$. O movimento reformador perdurou nos anos seguintes e ainda hoje é verificado ${ }^{24}$.

Écrits, Etudes et notes sur 1'arbitrage, vol. II, Paris: Dalloz, 1974, p. 7; e SATTA, Salvatore, Commentario al codice di procedura civile, vol. IV, n. 2, Milano: Giuffré, 1971, p. 166, que criticou o preconceito do monopólio estatal da jurisdição.

20 Utilizam a expressão "vent de réformes" SERAGLINI, Christophe; ORTSHEIDT, Droit de l'arbitrage interne et international, cit., p. 62.

21 As vantagens da arbitragem são bem conhecidas: a escolha dos próprios julgadores; a competência dos árbitros; a confidencialidade da arbitragem; a celeridade e a flexibilidade do procedimento. Em relação às vantagens e inconvenientes da arbitragem, v.: LOQUIN, Éric, Arbitrage. Définition. Nature juridique. Distinction avec d'autres institutions. Avantages et inconvénients, in JurisClasseur, Procédure civile, Fasc. 1005, Paris: LexisNexis, 2013, § 79 ss.; e CAHALI, Francisco José, Curso de Arbitragem, $3^{\circ}$ ed., São Paulo: Revista dos Tribunais, 2013, p. 85 ss.

22 Como salientam SERAGLINI, Christophe; ORTSHEIDT, Droit de l'arbitrage interne et international, cit., p. 63,"l'accueil de procédures arbitrales sur son territoire génère en soi une activité économique".

23 Nessa esteira, sem pretendermos ser exaustivos, é importante lembrar as seguintes reformas do direito arbitral, aprovadas nos anos setenta e oitenta: a belga de 1972 (Lei de 4 de julho de 1972), parcialmente alterada com a Lei de 27 de março de 1985, a inglesa de 1979 (Arbitration Act de 4 de abril de 1979), a francesa de 1980-81 (decretos n. 354, de 14 de maio de 1980 sobre a arbitragem interna, e n. 500, de 12 de maio de 1981 sobre a arbitragem internacional), a italiana de 1983 (Lei n. 28, de 9 de fevereiro de 1983), a austríaca de 1983 (Lei de 2 de fevereiro de 1983), a holandesa de 1986 (Lei de 2 de julho de 1986), a portuguesa de 1986 (Lei n. 31, de 29 de agosto de 1986), a suíça de 1987 (Lei federal de direito internacional privado n. 291, de 18 de dezembro de 1987), a espanhola de 1988 (Lei n. 36, de 5 de dezembro de 1988). Ademais, vale recordar a elaboração da Lei Modelo sobre a Arbitragem Comercial Internacional de 21 de junho de 1985 (posteriormente alterada em 2006) como um importante passo favorável à consolidação do instituto.

24 Cumpre lembrar a esse respeito (sem, todavia, a pretensão de apresentar uma lista exaustiva): a segunda e a terceira reforma italiana de 1994 (Lei n. 25, de 5 de janeiro de 1994) e de 2006 (Decreto legislativo n. 40, de 2 de fevereiro de 2006), a inglesa 
Nesse movimento de modernização da disciplina da arbitragem, como ressaltado anteriormente, a França foi tomada, na maioria das vezes, como modelo para os demais legisladores europeus. No que tange ao direito brasileiro, é cediço que a arbitragem começou a evoluir e a se desenvolver somente após a edição da LAB n. 9.307/1996, a qual normatizou a cláusula compromissória e eliminou a necessidade da homologação da sentença arbitral proferida no Brasil.

Assim, nos dias atuais, ninguém duvida da legitimidade da arbitragem e da possibilidade de a atividade jurisdicional ser desempenhada por particulares no âmbito da jurisdição (privada) ${ }^{25}$. Tanto na Europa quanto no Brasil, a arbitragem floresce na prática e se coloca ao lado do processo estatal como um meio adequado ou mais adequado de solução das controvérsias ${ }^{26}$.

(Arbitration Act de 17 de junho de 1996 ), a alemã de 1997 (Lei de 30 de dezembro de 1997), a belga de 1998 (Lei de 19 de maio de 1998), seguida por uma última e recente reforma em 2013 (Lei de 24 de junho de 2013), a espanhola de 2003 (Lei n. 60, de 23 de dezembro de 2003), seguida de uma reforma parcial em 2011 (Lei n. 11, de 20 de maio de 2011), a austríaca de 2006 (Lei de 13 de janeiro de 2006), a francesa de 2011 (Decreto n. 48, de 13 de janeiro de 2011) e a portuguesa de 2011 (Lei n. 63, de 14 de dezembro de 2011).

25 Nos dias atuais, os árbitros exercem, sem sombra de dúvida, uma atividade jurisdicional: eles resolvem controvérsias sobre um direito subjetivo, ditando a regra para o caso concreto mediante um processo em contraditório que se encerra com uma decisão vinculante às partes. Parece-nos, contudo, preferível falar em jurisdição privada para qualificar a atividade dos árbitros, ressaltando, desse modo, as peculiaridades da arbitragem em relação ao processo estatal, v.: PUNZI, Carmine, Disegno sistematico dell'arbitrato, cit., vol. I, p. 145 ss.; ID., Dalla crisi del monopolio statale della giurisdizione al superamento dell'alternativa contrattualità giurisdizionalità dell'arbitrato, in Rivista di diritto processuale, Cedam: Padova, 2014, n. 1, p. 1 ss., espec. p. 24; e BONATO, Giovanni, La natura e gli effetti del lodo arbitrale, cit.,p. 248 ss.

26 Sustentam essa perspectiva mais moderna CARMONA, Carlos Alberto, Arbitragem e processo, cit., p. 32; ID., A arbitragem como meio adequado de resolução de litígios, in GRINOVER, Ada Pellegrini; PELUSO, Antonio Cezar; RICHA, Morgana de Almeida (coords.), Conciliação e mediação: estruturação da política judiciária nacional, Riode Janeiro: Forense, 2011, p. 199 ss. e CINTRA, Antonio Carlos Araújo; PELLEGRINI GRINOVER, Ada; DINAMARCO, Cândido Rangel, Teoria geral do processo, $30^{\circ}$ ed., São Paulo: Malheiros, 2014, pp. 32-33. 


\section{A ARBITRAGEM INTERNACIONAL NA FRANÇA: $O$ MODELO DUALISTA}

Traçada, em apertada síntese, a evolução histórica do instituto, podemos focar a nossa atenção sobre o ordenamento francês.

Um ponto que merece destaque a respeito da França é a escolha do modelo dualista, ou seja, a adoção de uma regulamentação específica e diferenciada da arbitragem internacional a respeito daquela prevista para a arbitragem interna ou doméstica.

Conforme ao disposto do art. 1504 do CPC, a arbitragem é internacional quando forem colocados em jogo os interesses do comércio internacional ${ }^{27}$.

Vale salientar que a arbitragem internacional (objeto do título II do livro quarto do Código) caracteriza-se por um tratamento normativo mais permissivo, liberalizante e flexível a respeito do regime previsto para a arbitragem interna (objeto do título I do livro quarto do Código). Para frisar as divergências de regime entre as duas formas de arbitragem, recordamos, a título de exemplo, que: a convenção de arbitragem internacional não está sujeita a nenhuma condição de forma (art. 1507), ao passo que a

27 Diante da noção de arbitragem internacional, o conceito de arbitragem doméstica resulta como algo meramente residual, abarcando os procedimentos que colocam em jogo os interesses puramente locais.Ver sobre esse aspecto FOUCHARD, Philippe; GAILLARD, Emmanuel; GOLDMAN, Berthold, Traité de l'arbitrage commercial international, cit., p. 901.

Como já ficou exposto no item anterior, esse critério de internacionalização da arbitragem foi cunhado pela jurisprudência nos anos trinta do século passado a fim de afastar as regras restritivas e rigorosas da arbitragem interna e permitir, consequentemente, o desenvolvimento do instituto na área internacional. Foi notadamente a Corte de Cassação no caso Mardelé (Corte de Cassação, 19 de fevereiro, 1930, in Sirey, 1931, I, p. 1) que utilizou a noção de arbitragem internacional para admitir a validade de uma cláusula compromissória contida num contrato de venda internacional; cláusula que, segundo a legislação então em vigor, teria sido nula se a arbitragem tivesse sido interna. Na mesma linha de raciocínio, foi proferida depois a decisão Dambricourt (Corte de Cassação, 27 de fevereiro 1931, S., 1933, I, p. 1). Sobre esse aspecto, v.: LEBOULANGER, Philippe, La notion d' «intérêts» du commerce international, in Revue de l'arbitrage, Paris: LGDJ, 2005, n. 2, p. 487 ss.; e POUDRET, Jean-François; BESSON, Sébastien, Droit comparé de l'arbitrage international, LGDJ: Paris, 2002, p. 25. 
convenção de arbitragem interna deve ser estipulada por escrito, sob pena de nulidade (art. 1443); e a impugnação da sentença arbitral internacional não tem efeito suspensivo (art. 1526, parte $1^{\circ}$ ), enquanto a interposição da apelação ou da ação anulatória suspende a execução da sentença arbitral interna (art. 1496).

Impende frisar que o critério da internacionalização da arbitragem, previsto pelo CPC francês, é claramente de tipo econômico e se caracteriza pelo fato de que o litígio submetido ao árbitro tem por objeto uma operação que não se desenvolve economicamente em um só país, pois implica um movimento de recursos além das fronteiras, envolvendo o comércio transfronteiriço. Esse critério é puramente econômico, na medida em que faz abstração dos elementos jurídicos de extraneidade, como a nacionalidade, o domicílio e a residências das partes, o lugar da celebração do contrato objeto do litígio e a sede da arbitragem ${ }^{28}$.

Outros países europeus escolheram o modelo dualista. Assim, de maneira semelhante ao CPC francês, a Lei portuguesa de Arbitragem Voluntárian. 63, de 14 de dezembro de 2011, estabelece um critério econômico para determinar a internacionalidade da arbitragem. O legislador suíço, por seu turno, resolveu ditar uma regulamentação diferenciada para a arbitragem internacional (objeto dos artigos 176-194 da Lei de direito internacional privado de 18 de dezembro de 1987) que é definida com base num critério jurídico, assentado na presença de um elemento de extraneidade. Nos termos do art. 176, n. 1, da mencionada Lei suíça, a arbitragem é internacional quando, "pelo menos, uma das partes não tiver, no momento da conclusão da convenção de arbitragem, nem domicílio, nem residência habitual na Suíça"29.

28 Destaca a esse respeito a Corte de Apelação de Paris, no acórdão do 29 de março de 2001, in Revue de 1'arbitrage, Paris: LGDJ, 2001,n. 3, p. 543, queolegislador francês adotou «une définition exclusivement économique de l'arbitrage international selon laquelle il suffit que le litige soumis à l'arbitre porte sur une opération qui ne se dénoue pas économiquement dans un seul État». Na doutrina, v.: FOUCHARD, Philippe; GAILLARD, Emmanuel; GOLDMAN, Berthold, Traité de l'arbitrage commercial international, cit., p. 64 ss.; e SERAGLINI, Christophe; ORTSHEIDT, Jérôme, Droit de l'arbitrage interne et international, cit., p. 37 ss.

29 Já a arbitragem interna é regulada no Código de Processo Civil federal de 2008. 
Os sistemas acima mencionados (francês, português e suíço) contrapõem-se a outros ordenamentos que ditam um diploma jurídico unitário para o instituto, adotando o modelo de tipo monista. Adicionalmente, aponta-se que haveria um terceiro modelo intermediário (chamado também de monista "internacionalizante" ou "internacionalizado"), como será visto abaixo ${ }^{30}$.

Como é cediço, o monismo foi acolhido pela LAB $n$. 9.307/1996 ${ }^{31}$ que estabelece um diploma jurídico unitário para todas as arbitragens nacionais, não tendo relevância específica a presença de um elemento de ligação com mais de um país ${ }^{32}$. No Brasil, é estabelecida apenas a diferença entre a sentença arbitral nacional e a estrangeira, distintas com base no critério geográfico do lugar da prolação da sentença arbitral: é brasileira a sentença proferida dentro do território nacional e, correlatamente, é estrangeira a decisão emitida no exterior (LAB, art. 34) ${ }^{33}$.

Por fim, além desses dois modelos de base, há um terceiro denominado como monista "internacionalizante" ou misto, no qual vigora um diploma único com regras especiais para as arbitragens que apresentam elemento de ligação com mais de um ordenamento. Conforme este modelo intermediário, adotado, dentro outros, pelo

30 Para uma visão geral sobre os diferentes modelos monista, dualista e misto, v.: POUDRET, Jean-François; BESSON, Sébastien, Droit comparé de l'arbitrage international, cit., p. 23 ss.; e VERÇOSA, Fabiane, Arbitragem interna v. arbitragem internacional: breves contornos da distinção e sua repercussão no ordenamento jurídico brasileiro face ao princípio da autonomia da vontade, in TIBURCIO, Carmen; BARROSO, Luís Roberto (coord.), O direito internacional contemporâneo. Estudos em homenagem ao Professor Jacob Dolinger, Rio de Janeiro: Renovar, 2006, p. 421.

31 Nesse sentido, v.: CARMONA, Carlos Alberto, Arbitragem e processo, cit., p. 439; CAHALI, Francisco José, Curso de arbitragem, cit., p. 383; e BERALDO, Leonardo de Faria, Curso de arbitragem, São Paulo: Atlas, 2014, p. 32.

32 Isso significa que, segundo o modelo monista, a noção de arbitragem internacional tem um valor apenas descritivo, sem trazer nenhuma consequência relevante a respeito do regime jurídico do instituto.

33 Sobre a definição brasileira de sentença nacional, v.: CARMONA, Carlos Alberto, Arbitragem e processo, cit., p. 439, que considera-a como "mais objetiva, mais simples, embora tecnicamente criticável”; e VALENÇA FILHO, Clávio de Melo, Poder judiciário e sentença arbitral, Curitiba: Juruá Editora, 2002, p. 189, o qual salienta que a opção brasileira é "na contramão da moderna tendência internacional". 
legislador italiano ${ }^{34}$, o regime do instituto é unitário e apenas algumas regras especiais serão aplicadas se a arbitragem for internacional, como a respeito do regime da impugnação da sentença arbitral ${ }^{35}$.

\subsection{A TESE DA AUTONOMIA DA ARBITRAGEM INTERNACIONAL NA FRANÇA}

Igualmente a propósito do dualismo arbitral francês, impende lembrar que ilustres doutrinadores elaboraram já há alguns anos a tese da autonomia da arbitragem internacional em face de quaisquer leis estatais, teoria fundada no pressuposto de que a justiça arbitral possui uma natureza privada, não detendo uma "ligação orgânica com o detentor da soberania" e "não [estando] inserida em qualquer ordem preestabelecida" (OPPETIT, 1998, p.30) ${ }^{36}$. Desconectada de qualquer ordem jurídica estatal, a arbitragem se desnacionaliza e deslocaliza, integrando uma "ordem jurídica arbitral" de caráter internacional, autônoma e diferente das ordens jurídicas nacionais ${ }^{37}$. Essa teoria desvaloriza a importância da sede

34 Para um aprofundamento da evolução da arbitragem internacional na Itália, v.PUNZI, Carmine, Disegno sistematico dell'arbitrato, vol. I, cit., p. 290 ss.; e RICCI, Edoardo Flavio, La longue marche vers l'«internationalisation» du droit italien de l'arbitrage, in Les cahiers de l'arbitrage,IV,Paris: Lextenso, 2008,p. 191 ss.,

35 Ver sobre esse aspecto: RADICATI DI BROZOLO, Luca, Requiem per il regime dualista dell'arbitrato internazionale in Italia? Riflessioni sull'ultima riforma, in Rivista di diritto processuale, Padova: Cedam, 2010, n. 4,p. 1267 ss.; e BRIGUGLIO, Antonio, La dimensione transnazionale dell'arbitrato, in Rivista dell'arbitrato, Milano: Giuffré, 2005, n. 4, p. 706 ss.

36 Tradução livre da obra de OPPETIT, Bruno, Théorie de l'arbitrage, cit., p. 30: "la juridiction arbitral ... de caractère privé et sans lien organique avec le détenteur de la souveraineté, ne s'insère dans aucun ordre préétabli et jouit d'une parfaite autonomie dans le cadre des règles contractuelle, statutaires ou légales qui la gouvernent". A concepção da arbitragem como sistema autônomo e não nacional estava já contida no pensamento de GOLDMAN, Berthold, Les conflits de lois dans l'arbitrage international de droit privé, in Recueil des Cours de l'Academie de droit international de La Haye, 1963, t. 109, p. 347 ss., espec. p. 380. O tema da autonomia foi abordado também por FOUCHARD, Philippe, L'arbitrage commercial international, Paris: Dalloz, 1965. Sobre a evolução da doutrina francesa, v. BRAGHETTA, Adriana, A importância da sede da arbitragem, Rio de Janeiro: Renovar, 2010, p. 71 ss.

37 A expressão "ordem jurídica arbitral” foi utilizada em primeiro lugar por COHEN, Arbitrage et société, Paris: LGDJ, 1993, p. 23; depois retomada por outros 
da arbitragem e assevera que seriam os "direitos dos diferentes Estados que, quando são apreendidos de modo coletivo, formam um direito comum da arbitragem no qual é permitido encontrar a origem do poder de julgar dos árbitros"(GAILLARD, 2008, p.76) ${ }^{38}$.

Além de ser concebida como uma instituição autônoma, a arbitragem é conceituada de maneira universal na medida em que algumas regras se aplicam mesmo às arbitragens regidas por uma lei não francesa e sem nenhuma ligação com o ordenamento francês ${ }^{39}$. Este universalismo percebe-se, notadamente, a respeito da competência do juiz de apoio que possui o poder de nomear um árbitro não apenas em relação às arbitragens com sede na França, mas também acerca de qualquer arbitragem, desde que haja risco de denegação de justiça (CPC, art. 1505) ${ }^{40}$.

doutrinadores franceses, v.: CLAY, Thomas, L'arbitre, Paris: Dalloz, 2001, p. 215; ID., A sede da Arbitragem Internacional: entre "Ordem" e "Progresso", in Revista Brasileira da Arbitragem, n. 17, São Paulo: IOB, 2008, p. 37 ss.; ID., Le siège de l'arbitrage international entre "ordem" et "progresso", in Cahiers de l'arbitrage, V, Paris: Pedone, 2011, p. 21 ss.; GAILLARD, Emmanuel, Aspects philosophiques du droit de l'arbitrage international, Leiden-Boston: Martinus Nijhoff Publishers, 2008, p. 95 ss.; e PINSOLLE, Philippe, L'ordre juridique arbitral et la qualification de la sentence arbitrale de décision de justice international (à propos de l'arrêt Putrabali du 29 juin 2007), in Cahiers de l'arbitrage, vol. IV, Paris: Pedone, 2008, p. 110 ss.

38 Tradução livre de GAILLARD, Emmanuel, Aspects philosophiques du droit de l'arbitrage international, cit., p. 76: "ce sont les droits des différents Etats qui, lorsqu'ils sont appréhendés de manière collective, forment ce droit commun de l'arbitrage dans lequel il est permis de trouver l'origine du pouvoir de juger des arbitres".

39 Para uma visão geral da autonomia e universalidade da arbitragem na concepção francesa, v.: RACINE, Jean-Baptiste, Réflexions sur l'autonomie de l'arbitrage commercial international, in Revue de l'arbitrage, Paris: LGDJ, 2005, p. 305 ss.; GAILLARD, Emmanuel, Aspects philosophiques du droit de l'arbitrage international, cit., passim; ID., Souverainité et autonomie : réflexions sur les représentations de l'arbitrage international, in Journal de droit international, Paris: Lexisnexis, 2007, n. 4, p. 1163 ss.; CHAABAN, Rana, La reconnaissance des sentences arbitrales annulées dans le pays siège : emergence d'un ordre juridique arbitral ?, in CHAABAN, Rana (coord.), L'arbitrage detaché des lois étatique, Le Mans: Ed. L’Epitoge, 2012, p. 83 ss.; BILLARANT, Serge, Regard d'un internationaliste sur l'ordre juridique arbitral, in CHAABAN, Rana (coord.), L'arbitrage detaché des lois étatique, cit., p. 105 ss.: GRISEL, Florian, L'arbitrage international ou le droit contre l'ordre juridique, Paris: LGDJ, 2012, passim; e DEBOURG, Claire, Les contrariétés de décisions dans l'arbitrage international, Paris: LGDJ, 2012, p. 71 ss.

40 Sobre a competência dojuiz de apoio, ver CLAY,Thomas, L'appui du juge à l'arbitrage, 
Essa concepção autonomista da ordem jurídica arbitral contrapõe-se tanto à visão clássica territorialista e monolocalizadora (segundo a qual a arbitragem seria integrada unicamente no ordenamento jurídico do país escolhido como sede ${ }^{41}$ ), quanto à configuração intermediária e multilocalizadora (segundo a qual a arbitragem encontra a fonte da sua juridicidade não só na ordem jurídica do país da sede, mas também no conjunto das ordens prontas, verificadas certas condições, a reconhecer e executar a sentença $\operatorname{arbitral}^{42}$ ).

Ademais, frisamos que, conforme a escolha de uma das mencionadas representações, a autonomia da arbitragem é conceituada de maneira diferente. Enquanto, como vem sendo dito, os franceses, de um lado, concebem a autonomia da arbitragem de uma forma ampla e abrangente, considerada em face do mesmo sistema jurídico estatal, os brasileiros e os italianos, de outro lado, abordam tal autonomia de uma forma mais restrita no quadro das relações entre a arbitragem e a jurisdição estatal ${ }^{43}$.

Cabe frisar que, da tomada de posição sobre uma das mencionadas representações, decorre a resolução de várias questões práticas em matéria da arbitragem internacional ${ }^{44}$.

in CLAY, Thomas (coord.), Le nouveau droit français de l'arbitrage, cit., p. 343.

41 MANN, Francis A., «Lex facit Arbitrum», in International Arbitration. Liber Amicorum for Martin Domke, La Haye: Martinus Nijhoff, 1967, p. 157 ss.; POUDRET, JeanFrançois; BESSON, Sébastien, Droit comparé de 1'arbitrage international, cit., p. 83 ss.

42 Por essa concepção, v.: SERAGLINI, Christophe; ORTSCHEIDT, Jérôme, Droit de 1 'arbitrage interne et international, cit., p. 475.

43 Nessa perspectiva, DINAMARCO, Cândido Rangel, A arbitragem na teoria geral do processo, São Paulo: Malheiros, 2013, p. 210, considera a autonomia como "a premissa de maior magnitude no quadro das relações entre a arbitragem e a jurisdição estatal". O destacado autor acrescenta que tal autonomia "apoia-se em três pilares fundamentais", a saber: a "dispensa de homologação da sentença pelo juiz togado"; "a equivalência funcional" entre a sentença arbitral e a sentença togada; a "invulnerabilidade da sentença arbitral a qualquer censura de mérito a ser efetivada pelos órgãos do Poder Judiciário". Na mesma ótica, os italianos (PUNZI, Carmine, Disegno sistematico dell'arbitrato, vol. I, cit., p. 84 ss.) conceituam a autonomia da arbitragem em face à jurisdição estatal, no que tange ao laudo, cuja eficácia jurídica não está condicionada ao provimento de homologação.

44 Nesse sentido, veja-se as considerações de LUZZATO, Riccardo, A proposito del 
$\mathrm{Na}$ linha de raciocínio dessa parte da doutrina francesa, a arbitragem internacional manifesta a sua própria autonomia nos vários elementos do instituto, a saber, na configuração: da convenção de arbitragem, que deve ser avaliada "com base na vontade comum das partes, sem que seja necessária uma referência a uma lei estatal"45; do árbitro, qualificado como um "juiz internacional"46, cujo foro é o mundo inteiro ${ }^{47}$; e da sentença arbitral, definida como uma "decisão de justiça internacional", não integrada em nenhum ordenamento estatal ${ }^{48}$.

De qualquer forma, a mencionada visão francesa acerca da autonomia da arbitragem não parece ser isenta de críticas, na medida em que a efetividade do instituto fica, contudo, ligada aos ordenamentos nacionais que, por meio dos provimentos dos

momento attuale dell' arbitrato commerciale internazionale, in Diritto del commercio internazionale, Milano: Giuffré, 2012, n. 2, p. 441 ss., e GAILLARD, Emmanuel, Aspects philosophiques du droit de l'arbitrage international, cit.,p. 34 ss., obra naqual o autor expõe as três representações da arbitragem e as suas repercussões práticas.

45 No original: " $d$ 'après la commune volonté des parties, sans qu'il soit nécessaire de se référer à une loi étatique", elaborada na célebre decisão Dalico, na qual a primeira turma da Corte de Cassação francesa no dia 20 de dezembro de 1993 (publicada em Journal de droit international, Paris: Lexisnexis, 1994, n. 2, p. 432), enfatizou a autonomia da convenção de arbitragem.

46 Nesse sentido, v.: GAILLARD, Emmanuel; DE LAPASSE, Commentaire analytique du décret du 13 janvier 2011 portant réforme du droit français de l'arbitrage, cit., § 6 e $\S 121$, para os quais o árbitro possui o "statut d'un juge international".

47 Por essa visão, v. GAILLARD, Emmanuel, Aspects philosophiques du droit de l'arbitrage international, cit., p. 34 ss., ao passo que OPPETIT, Bruno, Théorie de l'arbitrage, cit., p. 30 , asseverava que o "árbitro não tem foro".

48 Nesse sentido, veja-se a decisão Putrabali da Corte de Cassação francesa de 29 de junho de 2007, in Revue de 1'arbitrage, Paris: LGDJ, 2007, n. 3, p. 507 ss., com observações de GAILLARD, Emmanuel; in Journal de droit international, Paris: Lexisnexis, 2007, n. 4, p. 1236 ss., com observações de CLAY, Thomas; in Int'1 Lis, Padova: Ipsoa, 2009, n. 3, p. 23 ss., com nota de BONATO, Giovanni: «la sentence internationale, qui n'est rattachée à aucun ordre juridique étatique, est une décision de justice internationale dont la régularité est examinée au regard des règles applicables dans le pays où sa reconnaissance et son exécution sont demandées». Sobre o tema ANCEL, Jean-Pierre, L'arbitrage international en France (Principes et système), cit., p. 209, assevera que «la sentence arbitrale a un statut juridique spécifique de décision juridictionnelle internationale: elle ne s'incorpore à aucun système juridique étatique, puisqu'elle émane d'une juridiction qui n'est elle-même intégrée dans aucun système judiciaire ou juridique étatique». 
juízes togados, outorgam à sentença a executividade e decretam sua anulação. Portanto, embora o legislador francês declare ter acolhido a ótica autonomista da arbitragem ${ }^{49} \mathrm{e}$ a jurisprudência despreze a anulação de uma decisão dos árbitros proferida no exterior (como será visto no próximo item), pode-se dizer que uma certa territorialidade abrange a sentença arbitral internacional proferida na França, já que esta deve ser homologada para tornarse executiva (CPC, arts. 1514 e ss.) e, ademais, fica sujeita à ação anulatória interposta perante o juiz togado (CPC, arts. 1518 e ss.). Tendo em mente essas reflexões, pensamos ser mais acertado sustentar que a mencionada autonomia da arbitragem não seja absoluta e total, pois esta não implica uma total independência dos ordenamentos nacionais ${ }^{50}$. Ao final, preferimos recusar a tese das sentenças "flutuantes" completamente desligadas dos ordenamentos nacionais, sendo impossível negar a presença de um elemento de territorialidade na arbitragem, mesmo em relação à legislação francesa ${ }^{51}$.

49 Nessa linha, veja-se o Rapport au Premier ministre relatif au décret n. 2011-48, du 13 janvier 2011, portant réforme de l'arbitrage in (www.legifrance.gouv.fr): "bien que le nouveau texte ne le prévoie pas expressément, il n'est pas question de revenir sur deux principes acquis en jurisprudence, dont la consolidation en droit positif nécessiterait l'intervention du législateur. Le premier est que l'Etat ou l'une de ses émanations ne peut invoquer son propre droit afin de s'opposer à l'application d'une convention à laquelle il a consenti (Civ. 1re, 2 mai 1966, Galakis). Le second est qu'une sentence internationale n'étant rattachée à aucun ordre juridique étatique, sa régularité doit être examinée au regard des règles applicables dans le pays où sa reconnaissance et son exécution sont demandées (Civ. 1re, 29 juin 2007)".

50 Nesse sentido, veja-se DEBOURG, Claire, Les contrariétés de décisions dans l'arbitrage international, cit., p. 74.

Com efeito, poder-se-ia sustentar uma autonomia total e mais abrangente da arbitragem se acolhêssemos a proposta de FOUCHARD, Philippe, Suggestions pour accroître l'efficacité internacionale des sentences arbitrales, in Revue de l'arbitrage, Paris: LGDJ, 1998, n. 4, p. 653 ss., acerca da extinção da nacionalidade da sentença e da supressão do controle do juiz da sede da arbitragem, para as sentenças arbitrais terem efeitos extraterritoriais. Todavia, para uma crítica a essa visão, v.: GAMA, Lauro Jr., Recusas fundadas no artigo V, (1), (E), da Convenção de Nova Iorque: peculiaridades de sua aplicação no Brasil, in WALD, Arnoldo; LEMES, Selma Ferreira (coord.), Arbitragem comercial internacional. A Convenção de Nova Iorque e o direito brasileiro, SãoPaulo: Saraiva, 2011, p. 235 ss., espec. pp. 272-273, pelo qual "deve-se preservar, por ser mais eficiente, o controle do laudo arbitral no país da sede".

51 Por essa razão há quem prefira falar de multilocalização da sentença, em vez de 


\subsection{A QUESTÃO DO RECONHECIMENTO DE UMA SENTENÇA ARBITRAL ESTRANGEIRA ANULADA NO PAÍS DE ORIGEM}

Nos exíguos limites deste estudo seria claramente impossível esgotar todos os aspectos da autonomia da arbitragem. Resolvemos, portanto, tratar do tema em relação à sentença arbitral que nos levará a enfrentar a questão do reconhecimento e da execução no exterior de uma decisão dos árbitros anulada no país em que foi proferida.

Sem termos a pretensão de chegar a uma abordagem minuciosa da jurisprudência francesa sobre o assunto, podemos apenas recordar que depois dos anos 80 do século passadoé pacífico o entendimento de que uma sentença arbitral pode ser reconhecida e executada na França, apesar da sua anulação pelo juiz togado do país em que foi proferida ${ }^{52}$.

A premissa de fundo sobre a qual se assenta essa solução é a de que a arbitragem, de acordo com a perspectiva autonomista e deslocalizadora do instituto, não está ligada ao ordenamento do país-sede e a sentença arbitral é uma "decisão de justiça internacional" ${ }^{53}$. Ademais, o fundamento normativo dessa solução

deslocalização, v.: MAYER, Pierre, L'insertion de la sentence dans l'ordre juridique français, in DERAINS, Yves (coord.), Droit et pratique de l'arbitrage international en France, Paris: Feduci, 1984, p. 81 ss., espec. p. 84; OPPETIT, Bruno, Théorie de l'arbitrage, cit., p. 86; de maneira semelhante SERAGLINI, Christophe; ORTSHEIDT, Jérôme, Droit de l'arbitrage interne et international, cit., p. 475 ss. O mesmo FOUCHARD, Philippe, La portée international de l'annulation de la sentence arbitrale dans son pays d'origine, in Revue de l'arbitrage, Paris: LGDJ, 1997, n. 3, p. 327 ss., espec. p. 352, assevera que, em seguida à homologação da sentença, haverá uma relocalização da sentença nos ordenamentos nacionais.

52 Remetemos, portanto, o leitor aos trabalhos da doutrina brasileira que resumem a evolução da jurisprudência francesa: CASELLA, Paulo Borba; GRUENBAUM, Daniel, Homologação de sentença arbitral estrangeira anulada, in Revista de Arbitragem e Mediação, vol. 9, São Paulo: Revista dos Tribunais, 2006, p. 207 ss.; e GAMA, Lauro Jr., Artigo V (inciso 1 "E"). Recusas fundadas no artigo V, (1), (E), da Convenção de Nova Iorque, de 1958, cit., p. 259 ss.; BRAGHETTA, Adriana, A importância da sede da arbitragem, cit., p. 125 ss.; e VALENÇA FILHO, Clávio de Melo, Poder judiciário e sentença arbitral,p. $165 \mathrm{ss}$.

Corte de Cassação francesa, acórdão de 29 de junho de 2007 (Putrabali), cit. 
baseia-se no art. VII, § 1, da Convenção de Nova Iorque de 1958 que resguarda a aplicação do direito nacional mais favorável. Com base nessa disposição, deverão ser aplicadas, em detrimento da Convenção de Nova Iorque, as disposições internas ou internacionais que estabelecem um tratamento mais favorável ao reconhecimento e execução da sentença arbitral estrangeira ${ }^{54}$. Com efeito, a regulamentação francesa é claramente mais favorável do que o sistema da Convenção dado que a primeira não contém entres as causas de não reconhecimento de uma sentença arbitral estrangeira (enumeradas no art. 1520 do CPC) o fato de ela ter sido anulada na sede ${ }^{55}$, ao contrário do que estabelece o art. V, let. e) da mencionada Convenção. Em razão da conjugação do art. VII, § $1^{\circ}$, da Convenção de Nova Iorque com o art. 1520 do CPC e com base na tese da autonomia da arbitragem a respeito dos ordenamentos nacionais, aos olhos do juiz francês, o objeto do controle será apenas a sentença arbitral estrangeira, sendo irrelevante a anulação do ato decretada no país sede da arbitragem ${ }^{56}$.

54 Sobre esse princípio, v.: FOUCHARD, Philippe; GAILLARD, Emmanuel; GOLDMAN, Berthold, Traité de l'arbitrage commercial international, cit., p. 153; LEE, João Bosco, A homologação de sentença arbitral estrangeira: a Convenção de Nova Iorque de 1958 e o direito brasileiro de arbitragem, in LEMES, Selma Ferreira; CARMONA, Carlos Alberto; MARTINS, Pedro Batista (coord.), Arbitragem. Estudos em homenagem ao Prof. Guido Fernando Silva Soares, in memoriam, São Paulo: Atlas, 2007, p. 175 ss., espec. p. 187; e BRAGHETTA, Adriana, A importância da sede da arbitragem, cit., p. 56.

55 É sabido que o art. V da Convenção de Nova Iorque prevê que: "O reconhecimento e a execução de uma sentença poderão ser indeferidos, a pedido da parte contra a qual ela é invocada, unicamente se esta parte fornecer, à autoridade competente onde se tenciona o reconhecimento e a execução, prova de que: [...] e) a sentença ainda não se tornou obrigatória para as partes ou foi anulada ou suspensa por autoridade competente do país em que, ou conforme a lei do qual, a sentença tenha sido proferida.".

56 Para a jurisprudência francesa, o art. VII da Convenção de Nova Iorque: "não limita o direito de ninguém de fazer prevalecer uma sentença arbitral da maneira e na medida admitida pela legislação do país onde a sentença é invocada; por conseguinte, o juiz francês não pode, quando a sentença foi anulada ou suspendida pela autoridade competente do país onde ela foi proferida, recusar a execução por este motivo, pois este não está enumerado no art. 1502 NCPC, mesmo se previsto no artigo V, I, e) da Convenção de Nova Iorque" (em tradução livre da: Corte de Cassação, 10 de março de 1993, in Revue de l'arbitrage, 1993, n. 2, Paris: LGDJ, p. 255 ss.). 
Avaliemos os prós e os contras desse posicionamento.

A solução descrita acima traz, sem dúvida, a vantagem de excluir a eficácia extraterritorial de decisões anulatórias de sentenças arbitrais fundadas em motivos torpes, fúteis e politicamente determinados ${ }^{57}$, mas, ao mesmo tempo, quebra a harmonia internacional das soluções sobre a mesma decisão ${ }^{58}$, reputada inválida no país da sede da arbitragem e executada em outro, alimentando adicionalmente o "forum shopping" na busca de Estados por executar a sentença anulada ${ }^{59}$.

À luz das vantagens e inconvenientes, apesar do entendimento uníssono da jurisprudência francesa em permitir o reconhecimento e a execução de uma sentença anulada no país de origem e nessa linha, seguido pela doutrina majoritária ${ }^{60}$, há, contudo, na França, alguns detratores desta solução ${ }^{61}$.

Quanto ao sistema brasileiro, a mencionada problemática suscita ainda dúvidas e perplexidades e divide os autores.

57 Nessa linha, v.CLAY, Thomas, Arbitrage et modes alternatifs, in Recueil Dalloz, Paris: Dalloz, 2006,p. 3035.

58 Nesse sentido, v.: BRAGHETTA, Adriana, A importância da sede da arbitragem, cit., p. 111, assevera que se "todos optarem pela linha francesa, estará fulminada qualquer coordenação que hoje ainda é exercida pela sede"; POUDRER, Jean-François, L'originalitédu droitfrançais del'arbitrage, in Revue internationale de droit comparé, Paris: Société de Legislation comparée, 2004, n. 1, p. 133 ss.; e BRIGUGLIO, Antonio, L'arbitrato estero, Padova: Cedam, 1999, p. 61.

59 ABBUD, André de Albuquerque Cavalcanti, Homologação de sentenças arbitrais estrangeiras, São Paulo: Atlas, 2008, p. 188, aponta o perigo de incentivar "a parte interessada a postular homologação do julgado de país em país no qual o vencido tenha bens, a fim de tentar conseguir seu reconhecimento em algum deles"; na mesma linha, DELPECH, Xavier, Admission de l'exequaturen France d'une sentence arbitrale étrangère annulée, in Recueil Dalloz, Paris: Dalloz, 2007, p. 1969.

60 V.: FOUCHARD, Philippe, La portée internationale de l'annulation de la sentence arbitrale dans son pays d'origine, cit., p. 329 ss.; GAILLARD, Emmanuel, Aspects philosophiques du droit de l'arbitrage international, cit., p. 95 ss. e 191 ss.; CLAY, Thomas, L'arbitre, cit., p. 215 ss.; e RACINE, Jean-Baptiste, Réflexions sur l'autonomie de l'arbitrage commercial international, in Revue de l'arbitrage, Paris: LGDJ, 2005, n. 2, p. 305 ss., espes. p. 327 ss.

61 Nesse sentido, v.: BOLLÉE, Sylvaine, Les méthodes du droit international privé à l'èpreuve des sentences arbitrales, Paris: Economica, 2004, p. 259 ss.; e CADIET, Loïc, L'exequatur d'une sentence arbitrale frappée d'un recours en annulation, in Droit maritime français, Paris: LGDJ, 1994, 28 ss. 
No Brasil, a doutrina majoritária considera que o STJ está proibido de reconhecer uma sentença anulada, a pedido da parte contra a qual ela é invocada ${ }^{62}$, mas, ao mesmo tempo, há uma parte autorizada da doutrina brasileira (mais inspirada da escola arbitralista francesa) que propugna a solução oposta ${ }^{63}$.

Sem pretendermos inovar nos argumentos, já objeto das reflexões de ilustres arbitralistas, é de se destacar que, ao nosso entender, a tese da jurisprudência francesa, acima relatada, parece dificilmente transponível para o ordenamento brasileiro.

Conforme o exposto, a solução que permite o reconhecimento de uma sentença anulada assenta-se na premissa teórica da autonomia e da ordem jurídica arbitral e baseia-se na conjugação do art. VII, $\S 1^{\circ}$, da Convenção de Nova Iorque com o art. 1520 do CPC francês. Em um país, tal como o Brasil, em que é muito forte na doutrina o apego à concepção territorialista da arbitragem e diante do art. 38 da LAB que contém entre as causas de recusa do pedido de homologação a anulação da sentença estrangeira, parece mais acertado excluir a possibilidade de o STJ admitir o reconhecimento de uma decisão anulada no país de origem diante da presença da produção de tal prova pelo réu ${ }^{64}$. Em outras palavras, de acordo com as cautelas que têm de ser adotadas no âmbito do direito comparado, parece-nos que as divergências estruturais entre

62 CARMONA, Carlos Alberto, Arbitragem e processo, cit., p. 473; BAPTISTA, Luiz Olavo, Sentença arbitral declarada nula no local onde proferida, in Revista Brasileira da Arbitragem, n. 37, São Paulo: IOB, 2013, p. 7 ss.; CASELLA, Paulo Borba; GRUENBAUM, Daniel, Homologação de sentença arbitral estrangeira anulada, cit., p. 207 ss.; BRAGHETTA, Adriana, A importância da sede da arbitragem, cit., p. 111; e ABBUD, André de Albuquerque Cavalcanti, Homologação de sentenças arbitrais estrangeiras, cit., p. 188.

63 Entre os partidários da possibilidade de outorgar o exequatur a uma sentença arbitral anulada no país de origem, recordamos, por todos,o posicionamento de: WALD, Arnoldo, Homologação de sentença arbitral estrangeira anulada pela justiça local no país da sede da arbitragem, in LEMES, Selma Ferreira; BALBINO, Inez, Arbitragem. Temas contemporâneos, São Paulo: Quartier Latin, 2012, p. 55 ss.

64 Nos raros casos em que a decisão de anulação prolatada pelo juiz togado seja contrária à ordem pública brasileira, poder-se-ia afastar esse pronunciamento para reconhecer a sentença arbitral estrangeira. Nessa linha, v.: CASELLA, Paulo Borba; GRUENBAUM, Daniel, Homologação de sentença arbitral estrangeira anulada, cit., § 4 . 
o sistema da arbitragem brasileiro e o francês impedem que possa ser transposta para o primeiro a solução adotada no segundo no que diz respeito ao reconhecimento e execução da sentença arbitral estrangeira.

\section{ARBITRAGEM SOCIETÁRIAITALIANA}

Esgotado o tema da arbitragem internacional francesa, podemos passar à abordagem da arbitragem societária italiana, cujo diploma legal apresenta regras inovadoras em prol do fortalecimento e da efetividade do instituto.

Como já foi dito na parte introdutória deste trabalho, a regulamentação da arbitragem societária italiana está contida no Decreto Legislativo n. 5/2003. Trata-se de uma forma especial de arbitragem voltada para dirimir as divergências entre os sócios e entre os sócios e a sociedade; as controvérsias oriundas de conflitos com os administradores, liquidantes e síndicos; e as disputas sobre a validade das deliberações assembleares.

Em particular, os artigos 34, 35 e 36 do mencionado Decreto Legislativo n. 5/2003 ditam regras sobre diversos aspectos do instituto, tais que: a arbitrabilidade objetiva; a arbitrabilidade subjetiva, ou seja, a abrangência subjetiva da cláusula compromissória; a nomeação dos árbitros; a intervenção de terceiros no processo arbitral; o poder dos árbitros de decretar medidas cautelares; e a publicidade do pedido arbitral. Vale recordar a esse propósito que, consoante o posicionamento da jurisprudência dominante italiana, as regras acerca da arbitragem societária são inderrogáveis: quando os sócios optarem pela via arbitral, inserindo uma cláusula compromissória estatutária, não é possível escolher a aplicação de regras diferentes, como as disposições da arbitragem de direito comum contidas no Código de Processo Civil ${ }^{65}$.

65 Nessa linha, veja-se a sentença da Corte de cassação italiana n. 24867 de 9 de dezembro de 2010, in Rivista trimestrale di diritto e procedura civile, 2011, n. 2, p. 629 ss., que recusou expressamente a chamada teoria do "duplo binário", ou seja, a da livre escolha entre a arbitragem especial e a arbitragem de direito comum para a solução das controvérsias societárias, reputando como imperativa a aplicação das regras da 
Cumpre frisar que, por expressa previsão do legislador, o recurso a tal meio de resolução de conflitos é admitido apenas nas sociedades comerciais (de pessoas e de capitais) depequenas e médias dimensões. As sociedades que recorrem ao mercado de capitais (ou seja, as sociedades "que fazem recurso ao mercado de capital de risco, segundo o artigo 2325-bis do Código Civil", como dispõe o art. 34, parte 1, do Decreto Legislativo sob enfoque) não têm acesso a essa forma especial da arbitragem. Afirma-se que o motivo dessa exclusão seria a consideração de que os investidores que adquirem participações societárias no mercado dificilmente tomam ciência de ter optado pela via arbitral. Por essa razão, não estariam aptos a consentir adequadamente à utilização da via arbitral ${ }^{66}$. Por outro lado, aponta-se que a extrema difusão do capital acionário poderia tornar muito difícil a utilização da arbitragem.

Dito isso, o exame aprofundado de cada uma das peculiaridades da arbitragem societária italiana extrapolaria os propósitos do presente estudo, impende, portanto, lançar o foco apenas sobre o tema da arbitrabilitade subjetiva e a regra sobre a nomeação dos árbitros.

A ideia de fundo que inspirou o legislador na elaboração das regras sobre a abrangência subjetiva da cláusula compromissória (que indica quais sócios são vinculados à arbitragem) é aquela segundo a qual a arbitragem deve ser a lei do grupo societário ${ }^{67}$.

Partindo dessa premissa sistemática, o mencionado Decreto trouxe duas disposições relevantes: a cláusula vincula todos os sócios, inclusive aqueles cuja qualidade de sócio é controvertida (artigo 34, parte 3); a sentença arbitral que vier a ser proferida em uma controvérsia societária será eficaz a respeito da sociedade e, por conseguinte, de todos os sócios (art. 35, parte 4).

Das mencionadas disposições extrai-se que os novos sócios (aqueles que vieram a adquirir as ações durante a vida da sociedade)

primeira forma de arbitragem.

66 Nesse sentido, DALMOTTO, Eugenio, L'arbitrato nelle società, cit., p. 67; e LUISO, Francesco Paolo, Appunti sull'arbitrato societario, cit., p. 706.

67 RICCI, Edoardo Flavio, Il nuovo arbitrato societario, cit., p. 524. 
estarão automaticamente vinculados pela cláusula compromissória, sem que seja necessária uma aceitação desta avença de maneira expressa e formal. Dito de outra forma, da aquisição da qualidade de sócio decorre automaticamente a sua vinculação à cláusula compromissória estatutária, reputando o legislador italiano suficiente uma aceitação tácita deste pacto ${ }^{68}$.

Vale lembrar que a mesma regra da aceitação tácita da cláusula compromissória se aplica aos administradores, liquidantes

e síndicos: quando eles aceitarem o encargo social, estarão automaticamente vinculados à cláusula compromissória a respeito das controvérsias que possam vir a surgir entre eles e a sociedade ${ }^{69}$.

Igualmente no tocante da arbitrabilidade subjetiva e com o intuito de favorecer a arbitragem, o legislador italiano trouxe uma importante disposição sobre a inserção da cláusula compromissória durante a vida da sociedade.

Adicionalmente vale destacarque, resolvendo as discussões surgidas na doutrina, o legislador optou por permitir a inserção da cláusula compromissória à maioria qualificada dos sócios (dois terços do capital social), concedendo, ao mesmo tempo, o direito de retirada aos sócios dissidentes ou ausentes na deliberação sobre a escolha da via arbitral. Em outras palavras, quando uma maioria dos sócios que representem pelo menos dois terços do capital social decide inserir a cláusula compromissória no estatuto, esta escolha

68 DALMOTTO, Eugenio, L'arbitrato nelle società, cit., p. 110; LUISO, Francesco Paolo, Appunti sull'arbitrato societario, cit., p. 712; e CARPI, Federico, Profili dell'arbitrato in materia di società, cit., p. 421. No direito brasileiro, MARTINS, Pedro Batista, Arbitragem no direito societário, São Paulo: Quartier Latin, 2012, p. 141 ss.

69 RICCI, Edoardo Flavio, Il nuovo arbitrato societario, cit., p. 534; DALMOTTO, Eugenio, L'arbitrato nelle società, cit., p. 116. Em sentido crítico a essa aceitação tácita da cláusula compromissória dos órgãos sociais, ver: LUISO, Francesco Paolo, Appunti sull'arbitrato societario, cit., p. 714; e CARPI, Federico, Profili dell'arbitrato in materia di società, cit., p. 417.

No Brasil, uma perspectiva semelhante é acolhida por: APRIGLIANO, Ricardo de Carvalho, Extensão da cláusula compromissória a partes não signatárias no direito societário, in Revista do Advogado, ano XXXIII, n. 119, São Paulo: AASP, abril 2013, p. 140 ss., espec. p. 150, segundo o qual se os administradores "aceitam o encargo, se firmam o contrato para exercer tais funções, parece também inegável que o fazem aceitando o estatuto social em todos os seus termos"; e MARTINS, Pedro Batista, Arbitragem no direito societário, cit.,p. 131 ss. 
torna-se obrigatória para a sociedade toda e a totalidade dos sócios. Contudo, o Decreto confere aos minoritários contrários à inclusão da cláusula o direito de retirada da sociedade que pode ser exercido no prazo de noventa dias; caso contrário, se os minoritários optarem por permanecer na sociedade, eles estarão vinculados automaticamente à cláusula.

A outorga do direito de retirada aos sócios dissidentes e ausentes decorre da inconstitucionalidade de qualquer forma de arbitragem obrigatória no ordenamento italiano. Como no Brasil, a arbitragem na Itália pode ser apenas voluntária ${ }^{70}$. Com base nessa previsão constitucional, se os sócios ausentes ou contrários à inclusão da cláusula compromissória não tivessem o direito de recesso, a arbitragem seria obrigatória a respeito deles.

Face ao exposto, fica claro que o legislador italiano decidiu recusar as outras soluções possíveis acerca da inclusão da cláusula compromissória na vida da sociedade: a que considera sempre necessária uma deliberação unânime de todos os sócios ${ }^{71}$; e a que visa à aplicação do princípio majoritário, sem outorgar o direito de recesso aos sócios minoritários dissidentes ${ }^{72}$.

70 Tanto na Itália quanto no Brasil, a opção pela via arbitral pode ser unicamente voluntária e facultativa, em razão da garantia da inafastabilidade da tutela jurisdicional (art. $5^{\circ}$, inc. XXXV, da Constituição Federal do Brasil e artt. 24 e 102 da Constituição da República italiana), ver nesse sentido: Corte Constitucional italiana, acordão n. 127 de 4 de julho de 1977; BONATO, Giovanni, La natura e gli effetti del lodo arbitrale, cit., p. 178 ss.; COMOGLIO, Luigi Paolo, Mezzi alternativi di tutela e garanzie costituzionali, in Rivista di diritto processuale, Milano: Giuffré, 2000, p. 318 e ss., espec. p. 370 s.; FAZZALARI, Elio, Contro l'arbitrato obbligatorio, in Rivista dell'arbitrato, Milano: Giuffré, 1993, p. 211 ss.; CARMONA, Carlos Alberto, Arbitragem e processo, cit., p. 36; BOSCOLO, Ana Teresa de Abreu Coutinho; BENETTI, Giovana Valentiniano, O Consensualismo como fundamento da arbitragem e os impasses decorrentes do dissenso, in Revista de Direito Empresarial, vol. 2, São Paulo: Revista dos Tribunais, 2014, p. 303 ss.; e BERALDO, Leonardo de Faria, Curso de arbitragem, cit., p. 41 ss.

71 No direito brasileiro, sustenta essa solução CARMONA, Carlos Alberto, Arbitragem e processo, cit.,p. 110.

72 Nodireitobrasileiro, propugna essa perspectiva aessa solução APRIGLIANO, Ricardo de Carvalho, Extensão da cláusula compromissória a partes não signatárias no direito societário, cit., p. 148, salientando que "a inclusão de cláusula compromissória, justamente em vista da sua natureza jurisdicional, não pode ser equiparada a um ato de abuso de poder de controle". 
Observa-se que a disposição italiana parece ter inspirado a redação do Projeto n. 406 de 2013, mencionado acima, que, além da alteração de alguns artigos da LAB, visa a acrescentar na Lei n. 6.404, de 15 de dezembro de 1976, (sobre as sociedades por ações), o artigo 136-A, assim redigido: “A aprovação dainserção de convenção de arbitragem no estatuto social, observado o quorum do artigo 136, obriga a todos os acionistas da companhia, assegurado ao acionista dissidente o direito de retirar-se da companhia mediante o reembolso do valor de suas ações (art.45). § $1^{\circ}$ - A convenção somente terá eficácia após o decurso do prazo e 30 (trinta) dias, contados da publicação da ata da Assembléia Geral que a aprovou".

De modo semelhante ao que ocorre na Itália, se o mencionado Projeto obtiver êxito no Brasil, a maioria qualificada dos sócios poderá inserir uma cláusula compromissória, podendo os minoritários sair da sociedade exercendo o direito de retirada ${ }^{73}$.

Por fim, merece particular destaque no que toca à arbitragem societária italiana a disposição, contida no artigo 34, parte 2 , do Decreto n. 5/2003, que impõe, sob pena de nulidade da cláusula compromissória, que a nomeação dos árbitros seja feita por um "terceiro estranho à sociedade" (segundo as palavras do decreto), a saber, por um sujeito que não tenha nenhuma ligação com a sociedade.

Forçoso é reconhecer que trata-se de uma solução viável e benéfica, na medida em que permite o desenvolvimento de uma arbitragem multipartes, evitando os problemas decorrentes da nomeação dos árbitros, mas que, ao mesmo tempo, é uma solução drástica, pois suprime uma das vantagens principais da arbitragem: a escolha dos próprios julgadores ${ }^{74}$.

73 Ver LEPORACE, Guilherme, Cláusulas compromissórias estatutárias. Análise da proposta de nova regulamentação sob a ótica da lógica econômica e da política legislativa, in Revista de Arbitragem e Mediação, vol. 40, São Paulo: Revista dos Tribunais, 2014, p. 63 ss.

74 O mencionado art. 34, parte 2, do decreto ${ }^{\circ}$ 5/2003 suscitou reações diferentes. Alguns autores louvaram a solução trazida pelo legislador (DALMOTTO, Eugenio, L'arbitrato nelle società, cit., p. 168). Em sentido crítico a respeito da regra da aceitação tácita da cláusula compromissória dos órgãos sociais, ver: RUFFINI, Giuseppe, La riforma dell'arbitrato societario, cit., p. 1526; RICCI, Edoardo Flavio, Il nuovo arbitrato 
Seja como for, nota-se que o Projeto n. 406/2013 de alteração da Lei de Arbitragem Brasileira não toma posição sobre o aspecto da designação dos árbitros numa arbitragem com múltiplas partes.

\section{CONCLUSÃO}

Concluindo este trabalho, esperamos ter contribuído ao aprimoramento do conhecimento dos leitores sobre alguns aspectos da arbitragem na França e na Itália, com o intuito de por em destaque alguns pontos interessantes, levando em conta a elaboração Projeto n. 406/2013 de alteração da Lei de Arbitragem Brasileira n. $9.307 / 1996$.

Ao final, queremos deixar claro que o escopo deste estudo não foi o de fornecer a melhor solução (ou, pior, tentar impô-la), mas apenas suscitar um debate sobre determinados temas relativos à arbitragem, colocando em confronto convergências e divergências encontradas nos sistemas objeto da nossa análise.

\section{REFERÊNCIAS}

ABBUD, André de Albuquerque Cavalcanti, Homologação de sentenças arbitrais estrangeiras, São Paulo: Atlas, 2008.

ANCEL, Jean-Pierre, L'arbitrage international en France (Principes et système), in AA.VV., L'arbitrage, Paris: Dalloz, 2009.

APRIGLIANO, Ricardo de Carvalho, Extensão da cláusula compromissória a partes não signatárias no direito societário, in Revista do Advogado, ano XXXIII, n. 119, p. 140-151. São Paulo: AASP, abril 2013.

BAPTISTA, Luiz Olavo, Sentença arbitral declarada nula nolocal onde proferida, in Revista Brasileira da Arbitragem,n. 37,p.7-28. São Paulo: IOB, 2013.

societario, cit., p. 505, ao passo que outros estudiosos (ZUCCONI GALLIFONSECA, Elena, Art. 34, in CARPI, Federico (coord.), Arbitrati speciali, cit., p. 97; CONSOLO, Sul campo «dissodato» della compromettibilità per arbitri, in Rivista dell'arbitrato, Milano: Giuffré, 2003, n. 2, p. 241 ss., espec. p. 254) formularam críticas sobre o dispositivo sob enfoque. 
BENEDETTELLI, Massimo; CONSOLO, Claudio; RADICATI DI BROZOLO,Luca, Commentario breve al diritto dell'arbitrato nazionale e internazionale, Pádua: Cedam, 2010.

BERALDO, Leonardo de Faria, Curso de arbitragem, São Paulo: Atlas, 2014.

BERNARDINI, Pietro, L'arbitrato nel commercio internazionale e negli investimenti internazionali, $2^{\circ}$ ed., Milano: Giuffré, 2008.

BIAVATI, Paolo, Il procedimento nell'arbitrato societario, in Rivista dell'arbitrato, Milano: Giuffré, n. 1, p. 27-50.2003.

BILLARANT, Serge, Regard d'un internationaliste sur l'ordre juridique arbitral, in CHAABAN Rana (coord.), L'arbitrage detaché des lois étatique, Le Mans: Ed. L'Epitoge, p. 105 ss. 2012.

BOLLÉE, Sylvain, Le droit français de l'arbitrage international après le décret n. 2011-48 du 13 janvier 2011, in Revue critique de droit international privé, Paris: Dalloz, n.2, p. 553-579. 2011,

BOLLÉE, Sylvaine, Les méthodes du droit international privé à l'èpreuve des sentences arbitrales, Paris: Economica, 2004.

BONATO, Giovanni, L'imparzialità e l'indipendenza degli arbitri alla luce della riforma del diritto societario, in LANFRANCHI, Lucio; CARRATTA, Antonio (coord.), Davanti al giudice. Studi sul processo societario, Torino: Giappichelli, 2005. p. 423 ss.

BONATO, Giovanni, L'ultima riforma francese dell'arbitrato, in Rivista dell'arbitrato, Milano: Giuffré, n.3, p.491-528. 2012.

BONATO, Giovanni, La natura e gli effetti del lodo arbitrale. Studio di diritto italiano e comparato, Nápoles: Jovene, 2012.

BOSCOLO, Ana Teresa de Abreu Coutinho; BENETTI, Giovana Valentiniano, O Consensualismo como fundamento da arbitragem e os impasses decorrentes do dissenso, in Revista de Direito Empresarial, vol. 2, São Paulo: Revista dos Tribunais, p. 303-341. 2014.

BRAGHETTA, Adriana, A importância da sede da arbitragem, Rio de Janeiro: Renovar, 2010. 
BRIGUGLIO, Antonio, L'arbitrato estero, Padova: Cedam, 1999.

BRIGUGLIO, Antonio, La dimensione transnazionale dell'arbitrato, in Rivista dell'arbitrato, Milano: Giuffré, n.4, p. 679-709. 2005.

BRIGUGLIO, Antonio; CAPPONI, Bruno, Commentario alle riforme del processo civile, vol. III, n. 2, Padova: Cedam, 2009.

CADIET, Loïc, L'exequatur d'une sentence arbitrale frappée d'un recours en annulation, in Droit maritime français, Paris: LGDJ, p. 28 ss. 1994.

CAHALI, Francisco José, Curso de Arbitragem, $3^{\circ}$ ed., São Paulo: Revista dos Tribunais, 2013.

CARMONA, Carlos Alberto, A arbitragem como meio adequado de resolução de litígios, in GRINOVER, Ada Pellegrini; PELUSO, Antonio Cezar; RICHA, Morgana de Almeida (coords.), Conciliação e mediação: estruturação da política judiciária nacional, Rio de Janeiro: Forense, p.199-210. 2011.

CARMONA, Carlos Alberto, A arbitragem no Código de Processo Civil brasileiro, Tese de doutorado, São Paulo, USP, 1990.

CARMONA, Carlos Alberto, Arbitragem e processo, $3^{\circ}$ ed., São Paulo: Atlas, 2009.

CARPI, Federico (coord.), Arbitrato, $2^{\circ}$ ed., Bologna: Zanichelli, 2007.

CARPI, Federico (coord.), Gli arbitrati speciali, Bologna: Zanichelli, 2008.

CARPI, Federico, Profili dell' arbitrato in materia di società, in Rivista dell'arbitrato, Milano: Giuffré, n.3, p.411-433.2003.

CASELLA, Paulo Borba; GRUENBAUM, Daniel, Homologação de sentença arbitral estrangeira anulada, in Revista de Arbitragem e Mediação, vol. 9, São Paulo: Revista dos Tribunais, p.242 ss. 2006.

CHAABAN, Rana, La reconnaissance des sentences arbitrales annulées dans le pays siège : emergence d'un ordre juridique arbitral ?, in CHAABAN, Rana (coord.), L'arbitrage detaché des lois étatique, Le Mans: Ed. L’Epitoge, p.83 ss. 2012. 
CHIOVENDA, Giuseppe, Istituzioni di diritto processuale civile, I, $2^{\circ}$ ed., Napoli: Jovene, 1935.

CINTRA, Antonio Carlos Araújo; PELLEGRINI GRINOVER, Ada; DINAMARCO, Cândido Rangel, Teoria geral do processo, $30^{\circ}$ ed., São Paulo: Malheiros, 2014.

CLAY, Thomas (Coord.), Le nouveau droit français de l'arbitrage, Paris: Lextenso, 2011.

CLAY, Thomas, «Liberté, Égalité, Efficacité» : La devise du nouveau droit français de l'arbitrage, in Journal de droit international, Paris: Lexisnexis, n. 2 e 4. p. 443-532. 2012.

CLAY, Thomas, Arbitrage et modes alternatifs, in Recueil Dalloz, Paris: Dalloz, 2006.

CLAY, Thomas, L'arbitre, Paris: Dalloz, 2001.

CLAY, Thomas, A sede da Arbitragem Internacional: entre "Ordem" e "Progresso", in Revista Brasileira de Arbitragem, n. 17, São Paulo: IOB, p. 37 - 56. 2008.

COHEN, Arbitrage et société, Paris: LGDJ, 1993.

COMOGLIO, Luigi Paolo, Mezzi alternativi di tutela e garanzie costituzionali, in Rivista di diritto processuale, Milano: Giuffré, 2000.

CONHEN, Le siège de l'arbitrage international entre "ordem" et "progresso", in Cahiers de l'arbitrage, V, Paris: Pedone, 2011.

CONSOLO, Sul campo «dissodato» della compromettibilità per arbitri, in Rivista dell'arbitrato, Milano: Giuffré, n.2. p.241-258. 2003.

CORNU, Gérard; FOYER, Jean, Procédure civile, Paris: PUF, 1958.

DALMOTTO, Eugenio, L'arbitrato nelle società, Padova: Zanichelli, 2013.

DAVID, René, Arbitrage et droit comparé, in Revue internationale de droit comparé, n.1. p. 5-18. 1959. 
DAVID, René; JAUFFRET-SPINOSI, Camille, Les grands systèmes de droit contemporains, $11^{\circ}$ ed., Paris: Dalloz, 2002.

DEBOURG, Claire, Les contrariétés de décisions dans l'arbitrage international, Paris: LGDJ, 2012.

DELPECH, Xavier, Admission de l'exequatur en France d'une sentence arbitrale étrangère annulée, in Recueil Dalloz, Paris: Dalloz, 2007.

DINAMARCO, Cândido Rangel, A arbitragem na teoria geral do processo, São Paulo: Malheiros, 2013.

DINAMARCO, Cândido Rangel, Fundamentos do processo civil moderno, $6^{\circ}$ ed., vol. I, São Paulo: Malheiros, 2010.

FAZZALARI, Elio, Contro l'arbitrato obbligatorio, in Rivista dell'arbitrato, Milano: Giuffré, p. 211 ss. 1993.

FOUCHARD, Philippe, L'arbitrage commercial international, Paris: Dalloz, 1965.

FOUCHARD, Philippe, L'arbitrage et la mondialisation de l'économie, in Mélanges en l'honneur de Gérard Farjat, Paris: Frison-Roche ed., p. 381 ss. 1999.

FOUCHARD, Philippe, La portée international de l'annulation de la sentence arbitrale dans son pays d'origine, in Revue de l'arbitrage, Paris: LGDJ, n. 3, p. 329-352 1997.

FOUCHARD, Philippe, Suggestions pour accroître l'efficacité internacionale des sentences arbitrales, in Revue de l'arbitrage, Paris: LGDJ, n.4. p. 653-672. 1998.

FOUCHARD, Philippe; GAILLARD, Emmanuel; GOLDMAN, Berthold, Traité de l'arbitrage commercial international, Paris: Litec, 1996.

GAILLARD, Emmanuel, Aspects philosophiques du droit de l'arbitrage international, Leiden-Boston: Martinus Nijhoff Publishers, 2008.

GAILLARD, Emmanuel, La jurisprudence de la Cour de cassation em matière d'arbitrage international, in Revue de l'arbitrage, Paris: LGDJ, n.4. p. 697-720. 2007. 
GAILLARD, Emmanuel, Souverainité et autonomie: réflexions sur les représentations de l'arbitrage international, in Journal de droit international, Paris: Lexisnexis, n.4. p. 1163 ss. 2007.

GAILLARD, Emmanuel; DE LAPASSE, Pierre, Commentaire analytique du décret du 13 janvier 2011 portant réforme du droit français de l'arbitrage, in Les Cahiers de l'arbitrage, Paris: Lextenso, n.1. p. 263 ss. 2011.

GAMA, Lauro Jr., Recusas fundadas no artigo V, (1), (E), da Convenção de Nova Iorque: peculiaridades de sua aplicação no Brasil, in WALD, Arnoldo; LEMES, Selma Ferreira (coord.), Arbitragem comercial internacional. A Convenção de Nova Iorque e o direito brasileiro, São Paulo: Saraiva, 2011.p.235-274.

GOLDMAN, Berthold, Les conflits de lois dans l'arbitrage international de droitprivé,in Recueil des Cours del'Academie de droit international de La Haye, t.109, p. 347-486. 1963.

GRAZIOSI, Andrea. Dall'arbitrato societario al tribunale delle imprese: a dieci anni dalla riforma del diritto societario, in Rivista trimestrale di diritto e procedura civile, Milano: Giuffré, n. 1. p. 77-110. 2014.

GRISEL, Florian, L'arbitrage international ou le droit contre l'ordre juridique, Paris: LGDJ, 2012.

HASCHER, Dominique, L'influence de la doctrine sur la jurisprudence française en matière d'arbitrage, in Revue de l'arbitrage, Paris: LGDJ, n.2. p. 391-419. 2005 .

JARROSSON, Charles; PELLERIN, Jacques, Le droit français de l'arbitrage après le décret du 13 janvier 2011, in Revue de l'arbitrage, Paris: LGDJ, n.1. p. 5-86. 2011.

LA CHINA, Sergio, L'arbitrato. Il sistema e l'esperienza, $4^{\circ}$ ed., Milano: Giuffré, 2011.

LEBOULANGER, Philippe, La notion d'«intérêts» du commerce international, in Revue de l'arbitrage, Paris: LGDJ, n. 2. p. 487-506. 2005 .

LEE, João Bosco, A homologação de sentença arbitral estrangeira: a 
Convenção de Nova Iorque de 1958 e o direito brasileiro de arbitragem, in LEMES, Selma Ferreira; CARMONA, Carlos Alberto; MARTINS, Pedro Batista (coord.), Arbitragem. Estudos em homenagem ao Prof. Guido Fernando Silva Soares, in memoriam, São Paulo: Atlas, p.177 ss. 2007.

LEPORACE, Guilherme, Cláusulas compromissórias estatutárias. Análise da proposta de nova regulamentação sob a ótica da lógica econômicaedapolíticalegislativa,in Revista de Arbitrageme Mediação, vol. 40, São Paulo: Revista dos Tribunais, p. 63-78. 2014.

LOQUIN, Eric, Arbitrage, Aperçu historique, Aperçu de droit comparé, in JurisClasseur, Procédure civile, Fasc. 1010, Paris: Lexisnexis, 2013.

LOQUIN, Éric, Arbitrage. Définition. Nature juridique. Distinction avec d'autres institutions. Avantages et inconvénients, in JurisClasseur, Procédure civile, Fasc. 1005, Paris: LexisNexis, § 79 ss . 2013.

LUISO, Francesco Paolo, Appunti sull'arbitrato societario, in Rivista di diritto processuale, Padova: Cedam, n.3. p. 705-726. 2003.

LUZZATO, Riccardo, A proposito del momento attuale dell'arbitrato commerciale internazionale, in Diritto del commercio internazionale, Milano: Giuffré, n.2. p.441-464. 2012.

MANDRIOLI, Cristanto; CARRATTA, Antonio, Diritto processuale civile, vol. III, $23^{\circ}$ ed., Turim: Giappichelli, 2014.

MANN, Francis A., «Lex facit Arbitrum», in International Arbitration. Liber Amicorum for Martin Domke, La Haye: Martinus Nijhoff, p.157184. 1967.

MARANI,Giovanni, Aspettinegoziali e aspetti processuali dell'arbitrato, Torino: Unione Tipografica-Editrice Torinese, 1966.

MARQUES, Claudia Lima; LIMA, Clarissa Costa de, Anotação ao PLS 406, de 2013 sobre arbitragem, in Revista de Direito do Consumidor, vol. 91, p. 407-414. 2014.

MARTINS, Pedro Batista, Arbitragem no direito societário, São Paulo: Quartier Latin, 2012. 
MAYER, Pierre, L'insertion de la sentence dans l'ordre juridique français, in DERAINS, Yves (coord.), Droit et pratique de l'arbitrage international en France, Paris: Feduci, p. 81-84. 1984.

MENCHINI, Sergio (coord.), La nuova disciplina dell'arbitrato, Padova: Cedam, 2010.

MOTULSKY, Henry, Écrits, Etudes et notes sur l'arbitrage, vol. II, Paris: Dalloz, 1974.

OPPETIT, Bruno, Théorie de l'arbitrage, Paris: Puf, 1998.

PICARDI, Nicola, ID., Le code de procédure civile français de 1806 et le monopole étatique de la juridiction, in CADIET, Loïc; CANIVET, Guy (coord.), 1806-1976-2006. De la commémoration d'un code à l'autre: 200 ans de procédure civile en France, Paris: Litec, 2006. p. 187 ss.

PINSOLLE, Philippe, L'ordre juridique arbitral et la qualification de la sentence arbitrale de décision de justice international (à propos de l'arrêt Putrabali du 29 juin 2007), in Cahiers de l'arbitrage, vol. IV, Paris: Pedone, p. 110 ss. 2008.

POUDRET, Jean-François, L'originalité du droit français de l'arbitrage, in Revue internationale de droit comparé, Paris: Société de Legislation comparée, n.1. p. 133 - 1492004.

POUDRET, Jean-François; BESSON, Sébastien, Droit comparé de l'arbitrage international, LGDJ: Paris, 2002.

PUNZI, Carmine, Dalla crisi del monopolio statale della giurisdizione al superamento dell'alternativa contrattualità giurisdizionalità dell'arbitrato, in Rivista di diritto processuale, Cedam: Padova, v.69, n.1. p.1-25. 2014.

PUNZI, Carmine, Disegno sistematico dell' arbitrato, voll. I,IIe III, $2^{\circ}$ ed., Padova: Cedam, 2012.

RACINE, Jean-Baptiste, Réflexions sur l'autonomie de l'arbitrage commercial international, in Revue de l'arbitrage, Paris: LGDJ, n. 2. p. 305-360. 2005.

RADICATI DI BROZOLO, Luca, Requiem per il regime dualista 
dell'arbitrato internazionale in Italia? Riflessioni sull'ultima riforma, in Rivista di diritto processuale, Padova:Cedam, n.4,p. 1267 ss. 2010.

RICCI, Edoardo Flavio, Il nuovo arbitrato societario, in Rivista trimestrale di diritto e procedura civile, Milano: Giuffré, vol.57, n. 2. p. 517-539. 2003.

RICCI,EdoardoFlavio,La longue marche versl'«internationalisation» du droit italien de l'arbitrage, in Les cahiers de l'arbitrage, vol. IV, Paris: Lextenso, 2008. p. 191 ss

RUBELLIN-DEVICHI, Jacqueline, L'arbitrage. Nature juridique. Droit interne et droit international, Paris: Dalloz, 1965.

RUFFINI, Giuseppe, La riforma dell' arbitrato societario, in Corriere Giuridico, Padova: Ipsoa, n. 11.p. 1524 ss. 2003.

SATTA, Salvatore, Commentario al codice di procedura civile, vol. IV, n. 2, Milano: Giuffré, 1971.

SERAGLINI, Christophe; ORTSCHEIDT, Jérôme, Droit de l'arbitrage interne et international, Paris: Montchrestien, 2013.

TARUFFO, Michele, L'insegnamento accademico del diritto processuale civile, in Rivista trimestrale di diritto e procedura civile, Milano: Giuffré, n.2. p. 551 ss. 1996.

TENELLA SILLANI, Chiara, L'arbitrato di equità, Milano: Giuffré, 2006.

VALENÇA FILHO, Clávio de Melo, Poder judiciário e sentença arbitral, Curitiba: Juruá Editora, 2002.

VERÇOSA, Fabiane, Arbitragem interna v. arbitragem internacional: breves contornos da distinção e sua repercussão no ordenamento jurídico brasileiro face ao princípio da autonomia da vontade, in TIBURCIO, Carmen; BARROSO, Luís Roberto (coord.), O direito internacional contemporâneo. Estudos em homenagem ao Professor Jacob Dolinger, Rio de Janeiro: Renovar, p. 421-449. 2006.

VIGORITI, Vincenzo, Verso un diritto comune dell'arbitrato: note sul lodo e la sua impugnazione, in Foro Italiano, Bologna: Zanichelli, parte V, p. 209/210-219/220. 1994. 
WALD, Arnoldo, A reforma da lei de arbitragem (uma primeira visão), in Revista de Arbitragem e Mediação, vol. 40, São Paulo: Revista dos Tribunais, p. 17 ss. 2014.

WALD, Arnoldo, Homologação de sentença arbitral estrangeira anulada pela justiça local no país da sede da arbitragem, in LEMES, Selma Ferreira; BALBINO, Inez, Arbitragem. Temas contemporâneos, São Paulo: Quartier Latin, 2012. p.55-72.

ZUCCONI GALLI FONSECA, Elena, Arbitrato societario: la Cassazione respinge la tesi del «doppio binario», in Rivista trimestrale di diritto e procedura civile, Milano: Giuffré, n.2, p. 629-641. 2011

\begin{abstract}
Agradecimentos
Aproveito a oportunidade para expressar o meu especial agradecimento à querida amiga Doutora Mariza Porta (Desembargadora do TJMG) e à Professora Dra. Juliana Cordeiro de Faria (Professora Adjunta de Processo Civil da Faculdade de Direito da UFMG), pelo convite formulado e organização do encontro. Registro, ainda, a minha gratidão ao Professor Dr. Fabricio Bertini Pasquot Polido (Professor Adjunto de Direito Internacional e Coordenador do Grupo de Arbitragem e Contratos Internacionais da Faculdade de Direito da UFMG), pelos comentários formulados e pelo debate, e à acadêmica Luiza Couto Chaves Brandão (Graduanda em Direito pela Faculdade de Direito da UFMG e Bolsista da Fundação de Amparo à Pesquisa do Estado de Minas Gerais), pela revisão técnica do texto final ora submetido à publicação.
\end{abstract}

